\title{
Testis Maturation Stages of Mud Crab (Scylla olivacea) Broodstock on Different Diets
}

(Peringkat Kematangan Testis Ketam Bakau (Scylla olivacea) Induk ke atas Diet yang Berlainan)

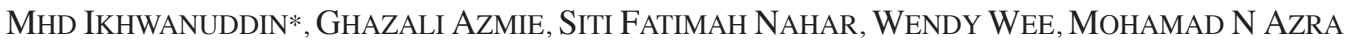 \\ \& AMBOK-BOLONG ABOL-MUNAFI
}

\begin{abstract}
The aim of this study was to investigate how various diets influence testis maturation stages in mud crab (Scylla olivacea) broodstock. Morphological and histological assessments were performed in triplicate (10 male crabs each). Daily, subject crabs were fed a squid (Loligo sp.) and a fish (Decapterus sp.) diet at 5-10\% of body weight. Diets were analyzed following methods from the Association of Analytical Communities (AOAC). In comparison to control (wild) crabs, the two diets generally did not cause significant differences $(\mathrm{p}>0.05)$ in body weight, carapace width and gonadosomatic index (GSI), except in the GSI of squid-fed crabs ( $\mathrm{p}<0.05)$. At the end of the experiment, crabs that reached Stage 3 testis maturation included were 6 fish-fed individuals and 23 squid-fed individuals. Additionally, differences in crude protein and fat levels across diets influenced the nature of male gonadal development. In conclusion, a squid diet was sufficient to induce Stage 3 testis maturation in Scylla olivacea within 60 days of culture. Our results prove the usefulness in developing appropriate feeding regimes for male Scylla olivacea broodstock.
\end{abstract}

Keywords: Association of Analytical Communities; crab reproduction; crustacean; nutrition; testis maturation

\section{ABSTRAK}

Tujuan penyelidikan ini adalah untuk mengkaji bagaimana pelbagai jenis diet makanan mempengaruhi peringkat kematangan testis ketam bakau (Scylla olivacea) induk. Penilaian morfologi dan histologi dilakukan dalam tiga kali pengulangan (10 ekor induk jantan setiap kali pengulangan). Kesemua ketam diberi makan diet makanan sotong (Loligo sp.) dan ikan (Decapterus sp.) sebanyak 5-10\% berat badannya setiap hari. Setiap diet makanan akan dianalisis mengikut kaedah daripada Association of Analytical Communities (AOAC). Secara amnya, jika dibandingkan dengan kumpulan ketam yang dikawal, kedua-dua jenis diet makanan tersebut tidak menunjukkan kesan yang signifikan (p>0.05) ke atas berat badan, saiz ukuran badan dan indeks kematangan gonadnya (GSI), kecuali indeks GSI ke atas ketam yang diberi makan sotong. Pada akhir kajian, hanya 6 ekor ketam yang diberi makan ikan dan 23 ekor ketam yang diberi makan sotong mencapai tahap 3 dalam peringkat kematangan testisnya. Sebagai tambahan, perbezaan antara protein mentah dan paras lemak dalam diet makanan telah mempengaruhi perkembangan gonad jantan secara semula jadi. Sebagai kesimpulan, diet makanan sotong sudah pun mencukupi untuk mendorong tahap 3 kematangan ketam jenis Scylla olivacea selama 60 hari ternakan. Keputusan kami adalah sangat berguna dalam membuktikan bahawa rejim pemakanan yang sesuai perlulah dibangunkan untuk induk jantan ketam Scylla olivacea.

Kata kunci: Association of Analytical Communities; kematangan testis; krustasia; nutrisi; pembiakan ketam

\section{INTRODUCTION}

Mud crabs (Scylla olivacea) have recently become one of the most important and commercially valuable aquaculture species in Malaysia (Waiho et al. 2016a, 2016 b). This increase in value has also led to a tremendous elevation in the exploitation of wild mud crab populations (Ikhwanuddin et al. 2015b) among South East Asian countries (Viswanathan \& Raffi 2015). Thus, long-term success and stability in the crab industry depends on appropriate maintenance of well-selected captive broodstock, including proper diets, controlled reproduction and successful offspring production (Fazhan et al. 2017). In terms of feed considerations, common natural diets such as squid, fish, cockles and polychaetes appear to improve crab reproduction and production (Ikhwanuddin et al. 2015a). Indeed, natural diets are sufficient to support survival and reproduction of captive crustacean broodstock (Azra \& Ikhwanuddin 2016). However, although diet-related changes to improve crab reproduction should focus on both male and female broodstock, most recent studies examining the effects of crab nutrition deals with ovarian development rather than testis maturation. Thus, there is an urgent need for research that can contribute to enhancing male broodstock quantity and quality in crab hatcheries. Besides increasing overall crab production, improving male quality should also raise the amount of berried females, a highly desired commodity in the markets. 
Generally, most brachyuran species exhibit three male gonadal maturation stages: Immature, maturing (intermediate) and matured (developed) (Soundarapandian et al. 2013; Waiho et al. 2017), with an additional rudimentary stage for some species (Marochi et al. 2013). During gonadal development, the absent of long-chain polyunsaturated fatty acids (LC-PUFA) in the maturation diet often affect the broodstock reproductive performance of Portunid crabs (Alava et al. 2007). To the best of our knowledge, the present study is among the first report investigating the effect of natural diets on the testis maturation and development of mud crab, especially genus Scylla.

A clear understanding of how diet make-up affects crab development is important for improving crab quality, particularly in terms of sexual maturation. An appropriate diet is thus a key part of developing efficient and successful breeding strategies in aquaculture (Ikhwanuddin et al. 2014). High-quality diets decrease crab mortality, resulting in greater sperm production. Excess sperm can then be cryopreserved for future use in artificial insemination (Ikhwanuddin et al. 2015c). In this study, we aimed to evaluate the effects of a squid (Loligo sp.) versus a fish (Decapterus sp.) diet on testis maturation stages in $S$. olivacea.

\section{MATERIALS AND METHODS}

\section{BROODSTOCK MANAGEMENT AND PREPARATION}

Ovigerous male mud crabs (121-140 g) were collected from the coastal waters of Kedah on the Malaysian Peninsular in May 2014. All were in the early stage of reproductive development. Crabs were transported alive to the Institute of Tropical Aquaculture marine hatchery and laboratory, where their sex and morphological characteristics were determined following existing criteria (Keenan et al. 1998). All broodstock were labeled, weighed and measured (carapace width, $\mathrm{CW}$; body weight, $\mathrm{BW}$ ), then randomly stocked into three indoor fiberglass tanks $(2 \mathrm{~m} \times 1 \mathrm{~m} \times 0.5$ m) at a density of 10 males tank $^{-1}$. All experimental tanks were filled with $75 \%$ filtered seawater $+25 \%$ tap water (salinity 25-27 ppt), kept at ambient temperatures (28$30^{\circ} \mathrm{C}$ ). Approximately $10-20 \%$ of the water was exchanged daily and aeration was provided to each tank. Tanks were outfitted with filters and contained pipes that served as refuge for the crabs (Waiho et al. 2015).

\section{EXPERIMENTAL DETAILS}

The experiment consisted of two treatments: A squid diet (SD) and a fish (FH) diet. Whole Loligo sp. and Decapterus sp. were used. All crabs were fed daily at 16:00 for two months (60 days). The diet ratio was 5-10\% total biomass, adjustable based on daily observation of residual feed per tank. Every morning, uneaten feed was removed before mortality and molting were recorded. At the end of the experiment, CW, BW and gonadosomatic index (GSI) were collected for comparison with the control group. We chose wild crabs as our control because their diets are highly varied, making them a suitable contrast to the fixed experimental diets. On Days 0, 30 and 60, a number of experimental and control crabs were randomly selected (to prevent bias) for subsequent analyses.

\section{TESTIS HISTOLOGY}

At the end of the 60-day experiment, all crabs were anesthetized on ice $\left(-20^{\circ} \mathrm{C}\right)$ for $15 \mathrm{~min}$ (to make sure that the crabs fully anesthetized and unconscious) and then sacrificed for morphological and histological analyses of the testes. Gonads were dissected and fixed in Bouin's solution (HT101128 SIGMA, Sigma-Aldrich (M), Malaysia) for $12 \mathrm{~h}$. Next, fixed tissues were dehydrated in ethanol, soaked in paraffin wax and cut into $5 \mu \mathrm{m}$ slices with a microtome (Leica Model RM 2135, Singapore). The slices were stained using hematoxylin and eosin before being attached to slides using Mayer's albumin, following published protocols (De-Lestang et al. 2003; Mura et al. 2005; Viau et al. 2006). Photomicrographs were taken with an Advance Research Microscope (Nikon Eclipse 80i, Japan) and the NIS-Elements D 2.30 software. Images were categorized based on published references of testis development (De-Lestang et al. 2003; Mura et al. 2005; Viau et al. 2006).

\section{PROXIMATE ANALYSIS}

Both experimental diets were analyzed for proximate composition (lipids, protein, fiber, ash and moisture) according to the AOAC (2002). Lipid concentrations were determined using Soxhlet extraction with petroleum ether as the solvent. The Kjeldahl method was used for protein analysis (AOAC 2002), with 6.25 set as the conversion factor. Diet moisture content was determined via ovendrying samples at $105^{\circ} \mathrm{C}$ for $12 \mathrm{~h}$, until reaching constant weight. Finally, ash content was measured after samples were placed in a $600^{\circ} \mathrm{C}$ furnace (Carbolite Gero, Germany) for $3 \mathrm{~h}$

\section{STATISTICAL ANALYSIS}

One-way analysis of variance (ANOVA) was used to determine whether diet treatments significantly affected testis maturation stages. Significant differences in means between treatments were identified using Tukey's post-hoc test. Significance was set at $p<0.05$.

\section{RESULTS}

\section{REPRODUCTIVE OUTPUT}

In general, no significant difference $(p>0.05)$ existed in the $\mathrm{BW}, \mathrm{CW}$ and GSI of crabs on different experimental diets, except the significantly lower GSI of SD-fed crabs $(p<0.05)$ compared with the control (Table 1). 
TABLE 1. Mean body weight (BW), carapace width (CW) and gonadosomatic index (GSI) of crabs on different experimental diets

\begin{tabular}{lccccccccc}
\hline & \multicolumn{3}{c}{ Day 0 } & \multicolumn{3}{c}{ Day 30 } & \multicolumn{3}{c}{ Day 60 } \\
\cline { 2 - 11 } \multicolumn{1}{c}{ Treatment } & $\begin{array}{c}\text { BW } \\
(\mathrm{g})\end{array}$ & $\begin{array}{c}\text { CW } \\
(\mathrm{cm})\end{array}$ & GSI & $\begin{array}{c}\text { BW } \\
(\mathrm{g})\end{array}$ & $\begin{array}{c}\text { CW } \\
(\mathrm{cm})\end{array}$ & GSI & $\begin{array}{c}\text { BW } \\
(\mathrm{g})\end{array}$ & $\begin{array}{c}\text { CW } \\
(\mathrm{cm})\end{array}$ & GSI \\
\hline Control & 121.6 & 7.91 & 0.16 & $\mathrm{n} / \mathrm{a}$ & $\mathrm{n} / \mathrm{a}$ & $\mathrm{n} / \mathrm{a}$ & $\mathrm{n} / \mathrm{a}$ & $\mathrm{n} / \mathrm{a}$ & $\mathrm{n} / \mathrm{a}$ \\
Squid-fed crabs & 126.8 & 7.88 & 0.05 & 133.2 & 8.17 & 0.08 & 173.9 & 8.67 & 0.34 \\
Fish-fed crabs & 152.9 & 8.05 & 0.28 & 154.1 & 8.31 & 0.32 & 155.6 & 8.56 & 0.36 \\
\hline
\end{tabular}

*BW, body weight; CW, carapace width; GSI, gonadosomatic index; $n=30 ; \mathrm{n} / \mathrm{a}$ : not available

\section{MORPHOLOGICAL AND HISTOLOGICAL ASSESSMENT ON} TESTIS DEVELOPMENT STAGES

Male S. olivacea reproductive organs are creamy to white in color and comprise two distinct regions, the testes and the shorter vas deferens (Figure 1). Testes are flat and coiled, located anterior to the hepatopancreas and below the cardiac stomach. Testis maturation was classified into three stages (1: immature, 2: maturing, 3: matured) based on external morphological characters and the presence of advanced spermatocytes (Table $2 \&$ Figure 1).

TABLE 2. Testis morphology across different maturation stages in Scylla olivacea after 0, 30, and 60 days on various diets (FH, fish diet; SD, squid diet; control, natural diet of wild crabs)

\begin{tabular}{|c|c|c|c|}
\hline Stage & Testis characteristics & Remarks & Results \\
\hline 1 & $\begin{array}{l}\text { Testes invisible to the naked eye; translucent vas } \\
\text { deferens; spermatogonia present }\end{array}$ & Immature & $\begin{array}{c}\text { Day 0: } \\
n=3(\text { control }) \\
n=3(\mathrm{FH}) \\
n=3(\mathrm{SD})\end{array}$ \\
\hline 2 & $\begin{array}{l}\text { Small testes and thin vas deferens; formation of } \\
\text { primary and secondary spermatocytes }\end{array}$ & Maturing & $\begin{array}{c}\text { Day } 30: \\
n=1(\mathrm{FH}) \\
n=3(\mathrm{SD}) \\
\text { Day } 60: \\
n=18(\mathrm{FH}) \\
n=1(\mathrm{SD})\end{array}$ \\
\hline 3 & $\begin{array}{l}\text { Testes swollen, opaque, and white; vas deferens } \\
\text { swollen and pink, contains spermatophore }\end{array}$ & Matured & $\begin{array}{c}\text { Day 60: } \\
n=6(\mathrm{FH}) \\
n=23(\mathrm{SD})\end{array}$ \\
\hline
\end{tabular}

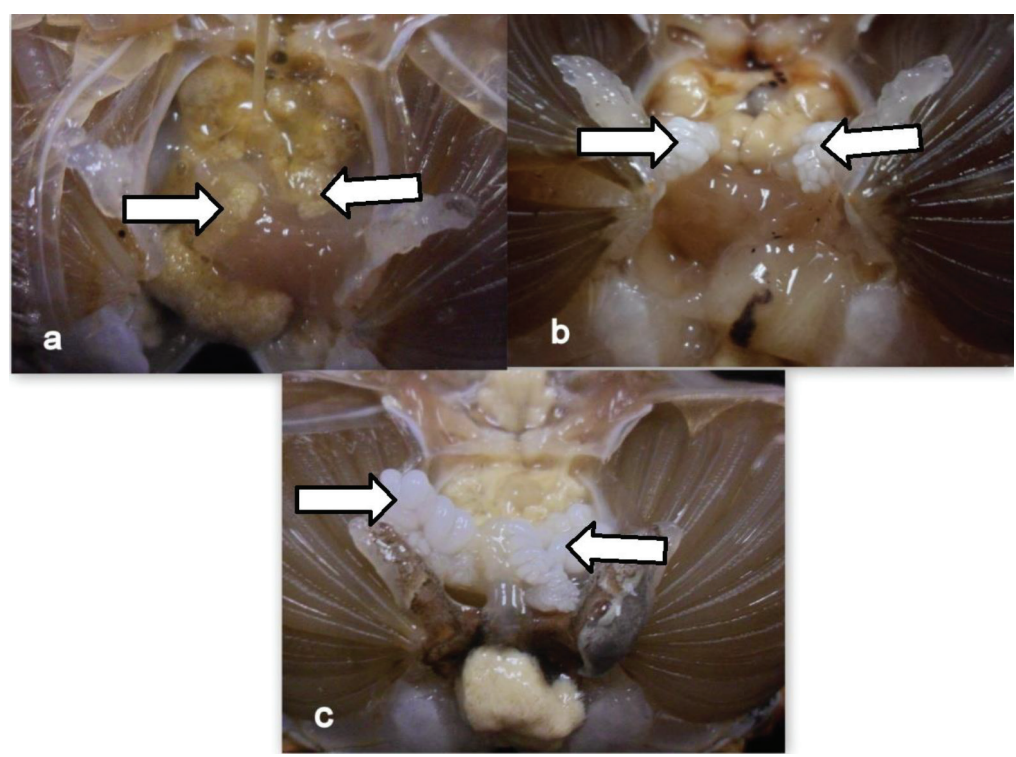

FIGURE 1. External testes morphology of Scylla olivacea after 60 days on two different diets aImmature (Stage I), b- Maturing (Stage II), and c- Matured (Stage III) 
All control and experimental crabs were at Stage 1 on Day 0. On Day 30, one FH-fed individual was at Stage 2 , whereas three SD-fed individuals were at Stage 3. By Day 60 (experiment end), 18 FH-fed crabs were at Stage 2, whereas 6 crabs reached Stage 3. In contrast, 23 SD-fed crabs reached Stage 3 and only 1 was at Stage 2 (Table 2). Among the 18 ( $3 \mathrm{crabs} / 3$ replications/treatment) cultured crabs, immature testes (Stage 1) possessed spermatogonia and primary spermatocytes (Figure 2(a)). Maturing testes (Stage 2) predominantly contained secondary spermatocytes, but primary spermatocytes were occasionally present (Figure 2(b)). Finally, spermatozoa were dominant in mature testes and spermatids were present (Figure 2(c)). We considered males to be sexually mature if they exhibited Stage 3 gonads with spermatozoa present.

\section{PROXIMATE ANALYSIS OF DIETS}

The squid diet contained more fat $(10.22 \%)$ and protein (77.7\%) than the fish diet (6.38\% fat and $55.31 \%$ protein) (Figure 3 ). The ash content in squid (6.65\%) was also much lower than in fish (7.42\%). Moisture content in the squid diet was $82.48 \%$ compared with $71.07 \%$ in the fish diet. However, fiber content in the two diets was similar (0.25$0.75 \%$ ). Variation in male gonadal development appeared to reflect dietary differences in crude protein and fat levels.

\section{DISCUSSION}

In this study, we demonstrated that diet nutritional quality influences reproductive development in male broodstock. Specifically, squid-fed crabs performed better than fish-fed crabs, due to the greater fat, protein, and moisture content in squid in term of testis maturation and development, however not for the $\mathrm{CW}$ and $\mathrm{BW}$. This outcome is consistent with previous research examining the effects of natural diets on reproductive development, showing that fat content is important for gonadal maturation in Scylla crabs (Djunaidah et al. 2003; Millamena \& Quinitio 2000). In other crustaceans such as tiger shrimp (Penaeus monodon), gonadal stimulation from high unsaturated fatty acid (HUFA) content in diets improves reproductive performance and egg hatchability (Millamena 1989). While these results are promising, research exists to show that supplementing a formulated diet with natural food is actually more consistent than natural-food-only diets in improving broodstock reproductive performance and enhancing seed production for crab hatcheries (Millamena \& Quinitio 2000).

Our experiments also allowed us to determine the maturity of male mud crabs through histological assessments of gonadal morphology. Instead, using gonadal color and structure, we classified crabs into three developmental stages: Stage 1 with spermatogonia present but unidentifiable vas deferens; Stage 2 with differentiated vas deferens, primary/secondary spermatocyte formation, but no spermatophores; and Stage 3 with swollen testes, along with prominent, tangled vas deferens containing spermatophores. However, due to the small sample size, the spermatophores were not found in the study compared to our previous results on the same species (Waiho et al. 2017). Earlier histological examinations of Scylla male gonad development found spermatophores in the anterior vas deferens but did not describe specific development stages (S. serrata, Robertson \& Kruger 1994). However, the overall structure of male reproductive organs in

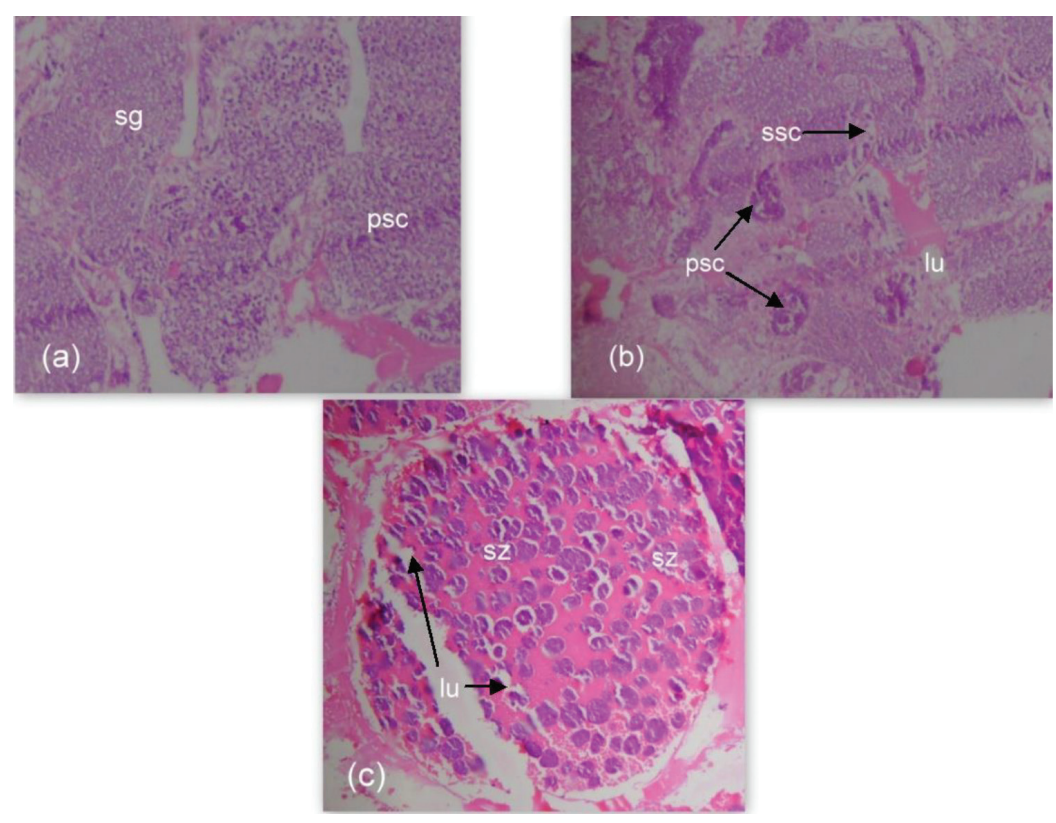

FIGURE 2. Histological sections of S. olivacea testes (a): immature (spermatogonia), (b): maturing (spermatocytes) and (c): matured (spermatids and spermatozoa). Sg, spermatogonia; psc, primary spermatocyte, ssc, secondary spermatocyte; sz, spermatozoa; lu, lumen 


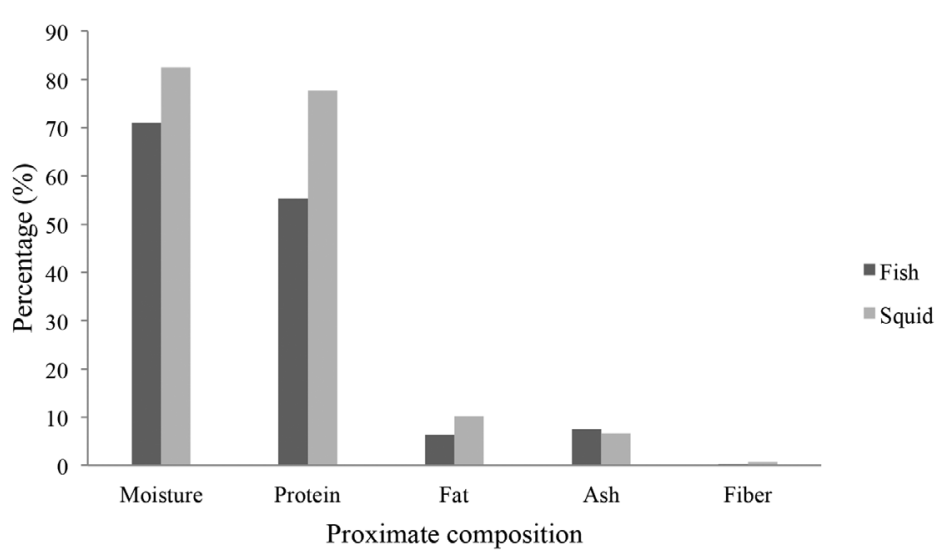

FIGURE 3. Proximate-analysis results of Scylla olivacea experimental diets (squid and fish)

S. olivacea (paired testes, commissure, paired vas deferens) is consistent with previous study (Waiho et al.2017) and is similar to the gonads of other portunid decapods, including Portunus sanguinolentus (Ryan 1967) and Goniopsis cruentata (Garcia \& Silva 2006). Moreover, our observed categories are generally consistent with several previous studies in other crab genera (portunid crab, De Lestang et al. 2003; anomuran crab, Viau et al. 2006). Another study on stone crab (Platyxanthus patagonicus) found five stages of development (Leal et al. 2008), but the first three were similar to the stages in our current study.

\section{CONCLUSION}

In conclusion, we demonstrated that a fish diet did not significantly differ from diets of wild crabs in affecting $S$. olivacea testis maturation, at least within 60 days. However, the squid diet significantly altered GSI after 30 and 60 days of treatment. Analyses of the two diets showed that squid has higher protein, fat and moisture content than fish, but less ash, whereas fiber content was similar across both diets. Future studies should therefore expand on our current findings to develop a natural diet mix that can improve testis quality. Regardless of diet, however, here we demonstrated clear morphological differences between immature, maturing and matured stages. These differences can act as a springboard for more research examining the relationship between testes growth stages and S. olivacea maturity. Finally, the results from our study can provide guidance for proper hatchery broodstock management.

\section{ACKNOWLEDGEMENTS}

This study was funded by the Ministry of Education, Malaysia under a Prototype Development Grant Scheme (PRGS, 2015-2017) - Establishment of artificial seed production for the Mud Crab, Genus Scylla, through the development of in-vitro fertilization and in-vitro culture protocols. We thank all staff at the Institute at Tropical Aquaculture and at the marine hatchery in the School of Fisheries and Aquaculture Sciences, Universiti Malaysia Terengganu for their technical assistance.

\section{REFERENCES}

Association of Analytical Communities (AOAC). 2002. Official Methods of Analysis. 17th ed. Washington DC: Association of Official Analytical Chemists.

Alava, V.R., Quinitio, E.T., dePedro, J.B., Priolo, F.M.P., Orozco, Z.G.A. \& Wille, M. 2007. Lipids and fatty acids in wild and pond-reared mud crab Scylla serrata (Forsskal) during ovarian maturation and spawning. Aquaculture Research 38: 14681477.

Azra, M.N. \& Ikhwanuddin, M. 2016. A review of maturation diets for mud crab genus Scylla broodstock: Present research, problems and future perspective. Saudi Journal of Biological Science 23: 257-267.

De-Lestang, S., Hall, N.G. \& Potter, I.C. 2003. Reproductive biology of the blue swimmer crab (Portunus pelagicus, Decapoda: Portunidae) in five bodies of water on the west coast of Australia. Fishery Bulletin 101: 745-757.

Djunaidah, S., Wille, M., Kontara, E.K. \& Sorgeloos, P. 2003. Reproductive performance and offspring quality in mud crab (Scylla paramamosain) broodstock fed different diets. Aquaculture International 11: 3-15.

Fazhan, H., Waiho, K., Wan Norfaizza, W.I., Megat, F.H. \& Ikhwanuddin, M. 2017. Inter-species mating among mud crab genus Scylla in captivity. Aquaculture 471: 49-54.

Garcia, T.M. \& Silva, J.R.F. 2006. Testis and vas deferens morphology of the red-clawed mangrove tree crab (Goniopsis cruentata) (Latreille, 1803). Brazilian Archives of Biology and Technology 49: 339-345.

Ikhwanuddin, M., Mohamed, S., Rahim, A.I.A., Azra, M.N., Jaaman, S.A., Bolong, A.M.A. \& Noordin, N.M. 2015a. Observation on the effect of natural diets on ovarian rematuration in blue swimming crab Portunus pelagicus (Linnaeus, 1758). Indian Journal of Fisheries 62: 124-127.

Ikhwanuddin, M., Lan, S.S., Abdul-Hamid, N., Fatihah-Zakaria, S.N.,Azra, M.N., Siti-Aisah, A. \& Abol-Munafi, A.B. 2015b. The embryonic development of orange mud crab, Scylla olivacea (Herbst, 1796) held in captivity. Iranian Journal of Fisheries Sciences 14: 885-895.

Ikhwanuddin, M., Yin, T.P., Menon, A.J., Jasmani, S. \& AbolMunafi, A.B. 2015c. Effect of different cryoprotectants and sperm densities of orange mud crab, Scylla olivacea (Herbst, 1796) for long-term storage of spermatozoa. Sains Malaysiana 44(9): 1283-1288.

Ikhwanuddin, M., Liyana,A.N., Azra, M.N., Bachok, Z. \& AbolMunafi, A.B. 2014. Natural diet of blue swimming crab, 
Portunus pelagicus at Strait of Tebrau, Johor, Malaysia. Sains Malaysiana 43(1): 37-44.

Keenan, C.P., Davie, P.J.F. \& Mann, D. 1998. A revision of the genus Scylla de Haan, 1833 (Crustacea: Decapoda: Brachyura: Portunidae). Raffles Bulletin of Zoology 46: 217-245.

Leal, G.A., Dima, J.B., Dellatorre, F.G. \& Baron, P.J. 2008. Schedule of reproductive events and maturity at size of the Patagonian stone crab Platyxanthus patagonicus (Brachyura, Platyxanthidae). Journal of Crustacean Biology 28: 262-269. Marochi, M.Z., Moreto, T.F., Lacerda, M.B., Trevisan, A. \& Masunari, S. 2013. Sexual maturity and reproductive period of the swimming blue crab Callinectes danae Smith, 1869 (Brachyura: Portunidae) from Guaratuba Bay, Parana State, Southern Brazil. Nauplius 21: 43-52.

Mura, M., Orru, F. \& Cau, A. 2005. Size at sexual maturity of the spider crab, Anamathia rissoana (Decapoda: Majoidea) from the Sardinian Sea. Journal of Crustacean Biology 25: 110-115.

Millamena, O.M. \& Quinitio, E. 2000. The effects of diets on reproductive performance of eyestalk ablated and intact mud crab Scylla serrata. Aquaculture 181: 81-90.

Millamena, O.M. 1989. Effect of fatty acid composition of broodstock diet on tissue fatty acid patterns and egg fertilization and hatching in pond-reared Penaeus monodon. Asian Fisheries Science 2: 127-134.

Robertson, W.D. \& Kruger, A. 1994. Size at maturity, mating and spawning in the portunid crab Scylla serrata (Forskal) in Natal, South Africa. Estuarine, Coastal and Shelf Science 39: 185-200.

Ryan, E.P. 1967. Structure and function of the reproductive system of the crab Portunus sanguinolentus (Herbst) (Brachyura: Portunidae). I. Male system. Proceedings of a Symposium on Crustacean. The Marine Biological Association of India, Part II. pp. 506-521.

Soundarapandian, P., Varadharajan, D. \& Boopathi, A. 2013. Reproductive biology of the commercially important portunid crab, Portunus sanguinolentus (Herbst). Journal of Marine Science: Research and Development 3: 1-9.

Viau, V.E., Greco, L.S.L., Bond-Buckup, G. \& Rodriguez, E.M. 2006. Size at the onset of sexual maturity in the anomuran crab, Aegla uruguayana (Aeglidae). Acta Zoologica 87: 253-264.
Viswanathan, C. \& Raffi, S.M. 2015. The natural diet of the mud crab Scylla olivacea (Herbst, 1896) in Pichavaram mangroves, India. Saudi Journal of Biological Sciences 22: 698-705.

Waiho, K., Fazhan, H., Jasmani, S. \& Ikhwanuddin, M. 2017. Gonadal development in males of the orange mud crab, Scylla olivacea (herbst, 1796) (Crustacea: Decapoda: Brachyura: Portunidae). Crustaceana 90: 1-19.

Waiho, K., Fazhan, H., Baylon, J.C., Wan Norfaizza, W.I. \& Ikhwanuddin, M. 2016a. Use of abdomen looseness as an indicator of sexual maturity in male mud crab Scylla spp. Journal of Shellfish Research 35: 1027-1035.

Waiho, K., Fazhan, H. \& Ikhwanuddin, M. 2016b. Size distribution, length-weight relationship and size at the onset of sexual maturity of the orange mud crab, Scylla olivacea in Malaysian waters. Marine Biology Research 12: 726-738.

Waiho, K., Mustaqim, M., Fazhan, H., Wan Norfaizza, W.I., Megat, F.H. \& Ikhwanuddin, M. 2015. Mating behaviour of the orange mud crab, Scylla olivacea: The effect of sex ratio and stocking density on mating success. Aquaculture Reports 2: 50-57.

Mhd Ikhwanuddin*, Ghazali Azmie \& Mohamad N Azra Institute of Tropical Aquaculture

Universiti Malaysia Terengganu

21030 Kuala Terengganu, Terengganu Darul Iman Malaysia

Siti Fatimah Nahar, Wendy Wee \& Ambok-Bolong Abol-Munafi School of Fisheries and Aquaculture Sciences

Universiti Malaysia Terengganu

21030 Kuala Terengganu, Terengganu Darul Iman Malaysia

*Corresponding author; email: ikhwanuddin@umt.edu.my

Received: 1 August 2016

Accepted: 25 September 2017 